\title{
Molecular Pathology of Gastritis
}

\author{
Alejandro H. Corvalán, Gonzalo Carrasco and Wilda Olivares \\ Pontificia Universidad Catolica de Chile, Santiago, \\ Chile
}

\section{Introduction}

Gastritis is an inflammation of the mucosa of the stomach, and has many etiologies. Gastritis can be classified as being acute or chronic. For the purpose of this chapter, we will focus only on chronic gastritis due to its relevance to gastric cancer. Among the causes of chronic gastritis are chronic bile reflux, stress, certain autoimmune disorders and bacterial infection, primarily Helicobacter pylori. Since 1870, both human and veterinary pathologists have described the presence of tiny curved bacteria within gastric mucosa, but the organisms were dismissed as irrelevant contaminants $(1,2)$. In 1947, when gastroscopy was first being used, Rudolf Schindler deemed gastritis as "one of the most debated diseases of the human body" and predicted that its significance would be discussed "for some time to come" (3). Schindler himself claimed that the "bacteriological etiology of chronic gastritis has not been convincingly proved in a single case" (3). In 1984, Warren and Marshall proposed that chronic "idiopathic" gastritis had a bacterial cause (i.e., H. pylori) (4). Their hypothesis was met with great skepticism. However, within a few years, the association between $H$. pylori gastritis, peptic ulcer, and gastric cancer came to be acknowledged and ultimately accepted (4). Subsequently, accurate morphological data were gathered by pathologic examination of autopsy material (5) and, later, of endoscopic biopsy specimens. As a result, distinct types and patterns of gastritis were recognized, which led to the conception, presentation, dismissal, and replacement of many different classification systems.

\section{Histological classification and grading of gastritis}

For the purpose of this chapter we decided to divided chronic gastritis in into two main categories, namely non-atrophic and atrophic gastritis (6). The main purpose of this classification is to individualize high-risk gastritis subgroup that subsequently might develop to gastric cancer. In the gastric mucosa, atrophy is defined as the loss of appropriate glands. Atrophic gastritis, resulting mainly from long-standing H. pylori infection, and is a major risk factor for the onset of gastric cancer. The extent and site of the atrophic changes significantly correlate with cancer risk $(6,7)$. Two main types of atrophic gastritis can be recognized, one characterized by the loss of glands, accompanied by fibrosis or fibromuscular proliferation in the lamina propria, and the other characterized by the replacement of the normal mucosa into an intestinal type of mucosa (i.e. intestinal metaplasia) (8). The first can be assessed with the new Operative Link for Gastritis Assessment (OLGA) staging system for atrophy risk assessment (9) which ranks the risk of gastric cancer according to the extension and severity of gastric atrophy (Fig. 1 and Table 1). 


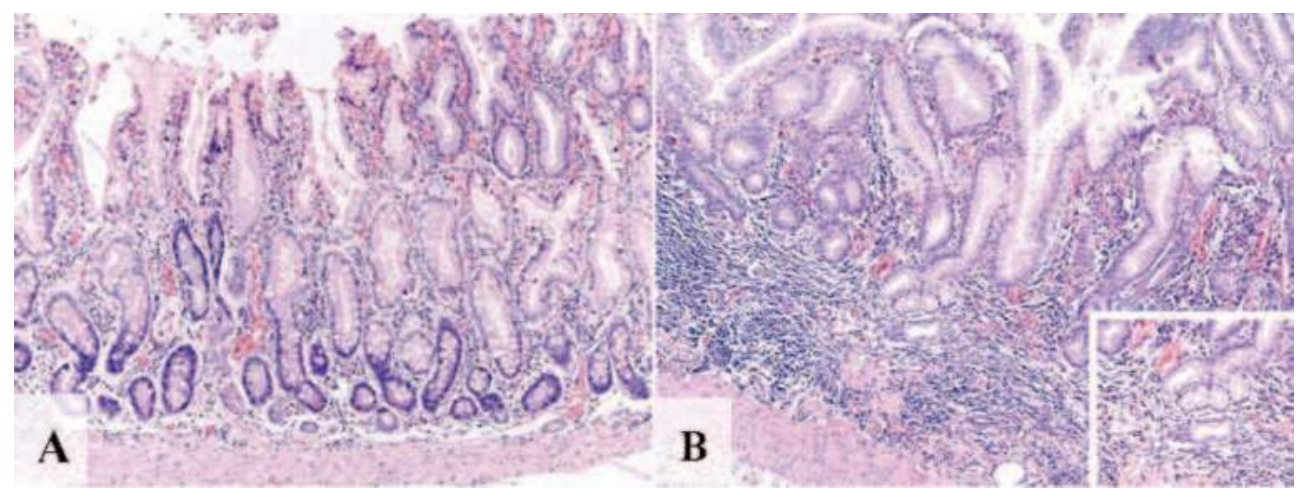

Fig. 1. Atrophy is the loss of appropriate glands. (A; H\&E 10x) Antral gastric mucosa with accentuated atrophy because replacement by extensive intestinal metaplasia. (B; H\&E 10x; square 20x) Fundic-corporal gastric mucosa with extensive loss of gastric glands, partially replaced by pseudo-pyloric metaplasia.

\begin{tabular}{|c|c|c|c|c|c|}
\hline & \multirow{2}{*}{ Atrophy Score } & \multicolumn{4}{|c|}{ Corpus } \\
\hline & & $\begin{array}{l}\text { No Atrophy } \\
\text { (score 0) }\end{array}$ & $\begin{array}{l}\text { Mild Atrophy } \\
\text { (score 1) }\end{array}$ & $\begin{array}{l}\text { Moderate Atrophy } \\
\text { (score 2) }\end{array}$ & $\begin{array}{l}\text { Severe Atrophy } \\
\text { (score } 3 \text { ) }\end{array}$ \\
\hline \multirow{4}{*}{$\begin{array}{c}\mathrm{A} \\
\mathrm{n} \\
\mathrm{t} \\
\mathrm{r} \\
\mathrm{u} \\
\mathrm{m}\end{array}$} & $\begin{array}{l}\text { No Atrophy (score 0) } \\
\text { (including incistura angutaris) }\end{array}$ & STAGE 0 & STAGEI & STAGE II & STAGE II \\
\hline & $\begin{array}{l}\text { Mild Atrophy (score 1) } \\
\text { (including incissira angularis) }\end{array}$ & STAGE I & STAGEI & STAGE II & STAGE: III \\
\hline & $\begin{array}{l}\text { Moderate Atrophy (score 2) } \\
\text { (including incisura angularis) }\end{array}$ & STAGE II & STAGE II & STAGE III & STAGE IV \\
\hline & $\begin{array}{l}\text { Severe Atrophy (score 3) } \\
\text { (including imcisara angtiaris) }\end{array}$ & SIAGIE III & SIAGE III & SIAGiE IV & SIAGE IV \\
\hline
\end{tabular}

No atrophy $(0 \%)=$ score 0 ; mild atrophy $(1-30 \%)=$ score $1 ;$ moderate atrophy $(31-60 \%)=$ score $2 ; 9$ severe atrophy $(>60 \%)=$ score 3 . These scores $(0-3)$ are used in the OLGA staging assessment in each 10 compartment. Taken from Rugge et al., Dig Liver Dis 2011;43:S373-84 with permission of Elsevier.

Table 1. The OLGA staging frame. Atrophy is scored as the percentage of atrophic glands and scored on a four-tiered scale.

Cross-sectional and long-term follow-up trials conducted in various epidemiologic settings have consistently associated OLGA stages III and IV with a higher risk of gastric cancer vs. low-risk OLGA stages [ie, stages 0, I, and II]) (6). The latter can be assessed based on whether the metaplastic epithelium phenotype resembles large bowel epithelia (colonic-type intestinal metaplasia) or the small intestinal mucosa $(6,10,11)$. This classification was made by determining the histochemical phenotype of intestinal metaplasia (IM) using high-iron 
diamine stain. Cross-sectional descriptive studies and follow-up trials have consistently supported a strong association between OLGA stages and IM histochemical phenotypes, where IM of small intestinal type (type I) significantly prevailed in low-risk atrophic stages and high-risk OLGA stages were associated with IM of types II and III (6). Accordingly, epidemiological studies have shown that degree of severity for non-metaplastic atrophy influences the prevalence of IM and that the severity of IM influences the prevalence of dysplasia (12). These results support the concept that IM and dysplasia are linked in a sequential cause-effect relationship and confirm a proposed model for the pathogenesis of gastric cancer (11). However, risk assessment for gastric cancer development has not been well defined for other premalignant conditions (13).

\section{Genetics bases of gastritis}

The seminal proposal of a genetic model for tumorigenesis by Fearon \& Vogelstein (14) and, more recently, the categorization of different cancers types into six physiological groups proposed by Hanahan \& Weinberg (15) provide a theoretical framework for understanding the genetic and epigenetic bases of gastritis as well as premalignant conditions of gastric cancer. Thus, gastritis, and gastric cancer premalignant conditions should be understood as a disturbance in the balance between tumor suppressor genes and oncogenes. p53 gene (16) and the c-erbB2 oncogene $(17,18)$ were the first tumor suppressor gene and oncogene to be identified in gastric cancer, respectively. From these reports, a growing number of genes have been identified (19). However, different studies have shown that mutation and/or deletion is an infrequent mechanism of inactivating well stablished tumor suppressor genes such as E-cadherin $(20,21)$. Similarly, loss of heterozygosity (LOH) and microsatellite instability (MSI) have been frequently found in gastric cancer (19, 22, 23). However, mutations of the DNA mismatch repair genes, hMSH2 and hMLH1, responsible for LOH and MSI, are not frequently encountered $(19,24)$. Taken together, these observations suggest that genetic alterations do not completely explain the accumulation of genetic damage observed in gastric cancer and premalignant conditions. In this scenario, the recent inactivation of tumor suppressor genes by a novel epigenetic mechanisms, DNA methylation, has been proposed as an alternative mechanism to mutation and/or deletions (25). The best-documented inactivation by DNA methylation in gastric cancer is the silencing of DNA mismatch repair genes hMSH2 and hMLH1 (26). This inactivation is responsible for the development of the majority of MSI-related gastric cancers. As such, this inactivation leads to subsequent mutations in simple repetitive sequences within genes that are critical to the neoplastic process (23).

\section{Epigenetic bases of gastritis}

Epigenetic processes control the packaging and function of the human genome and contribute to normal development and disease (27). Epigenetic mechanisms such as DNA methylation, histone modifications and microRNAs (28) virtually affects all of the pathways in the cellular network, such as DNA repair, cell cycle, and apoptosis (25). DNA methylation, a process in which cytosines acquire a methyl group in 5 ' position only if they are followed by a guanine (CpG site) (28) is an early event in carcinogenesis (29-31). In addition, DNA metylation has been recently considered as an excellent candidate to explain 
how certain environmental factors may increase the risk of cancer (32). Accordingly, an emerging catalog of specific tumor suppressor genes inactivated by DNA methylation in gastrointestinal tumors has been established (33-36). Most of these studies has been performed by Methylation Specific - Polymerase Chain Reaction (MS-PCR), the most popular assay for DNA methylation (37). In MSP sodium bisulphite is used to convert cytosine residues to uracil residues in single-stranded DNA under conditions whereby 5methylcytosine remains non-reactive. The converted DNA is amplified with specific primers and since all the cytosine residues remaining in the sequence represent previously methylated cytosines, MSP approach allows to detect DNA isolated from fewer than 100 cells $(38,39)$.

\section{DNA methylation and gastritis}

There are limited reports on DNA methylation analysis in gastritis and premalignant lesions of gastric cancer. Kang et al (40) tested five genes (p16, hMLH1, DAP-kinase, THBS1, and TIMP-3) in a series of 64 carcinomas and 179 premalignant conditions (69 chronic gastritis, $49 \mathrm{IM}$ and 61 gastric adenomas) to identify two different classes of methylation patterns, preferential methylation of THBS-1 and TIMP-3 in chronic gastritis and IM and preferential methylation of hMLH1 and p16 in intestinal metaplasia, displasia and gastric cancer. These findings suggest that DNA methylation occur early in multistep gastric carcinogenesis and specific patterns of DNA methylation on specific genes ocurr along these steps (40). A subsequent study identified specific patterns of DNA methylation associated with aging after testing 11 genes in 268 premalignant gastritis (41). DNA methylation was found in increasingly frequency as a function of aging in five genes (DAP-kinase, E-cadherin, p14, THBS1 and TIMP-3), whereas the other genes (COX-2, GSTP1, MGMT, hMLH1, p16, and RASSF1A) were rarely methylated (41). Since E-cadherin was methylated at high frequency, a further study demonstrated, for the first time, that DNA methylation of promoter region of E-cadherin was associated with $H$. pylori infection. This association was independent of the age and or type of gastritis (42). Similarly, Maekita et al (43) analyzed the effect of $H$. pylori infection on DNA methylation of several genes (HAND1, HRASLS, LOX, p16, P41ARC and THBD) by quantitative methods in $H$. pylori negative and positive healthy donors and gastric cancer patients. Among healthy donors, methylation levels were up to 300 -fold higher in H. pylori positives than in H. pylori negatives (43). However, among gastric cancer patients, methylation levels were only up 30-fold higher, suggesting that $H$. pylori infection induces DNA methylation of several genes beyond E-cadherin (43). Chan et al (32) evaluate the effect or eradication of H.pylori on DNA methylation in gastric mucosa. Before and after the treatment DNA methylation of E-cadherin was detected in $46 \%$ and $17 \%$ of 41 patients, respectively (Fig. 2). Histological evaluation after the treatment, showed chronic inactive gastritis in most of the cases. A similar results was communicated by Leung et al (44), although they evaluated tissues from the antrum and corpus of $H$. pylori-infected subjects at baseline and after one year of successful $H$. pylori eradication. These authors identified a significant reduction in the methylation density of the promoter region and exon 1 of the E-cadherin gene by bisulfite DNA sequencing. Taken together, these results demonstrated that eradication of $H$. pylori infection reverses E-cadherin promoter hypermethylation and suggest an environmental effect on DNA methylation (32). 


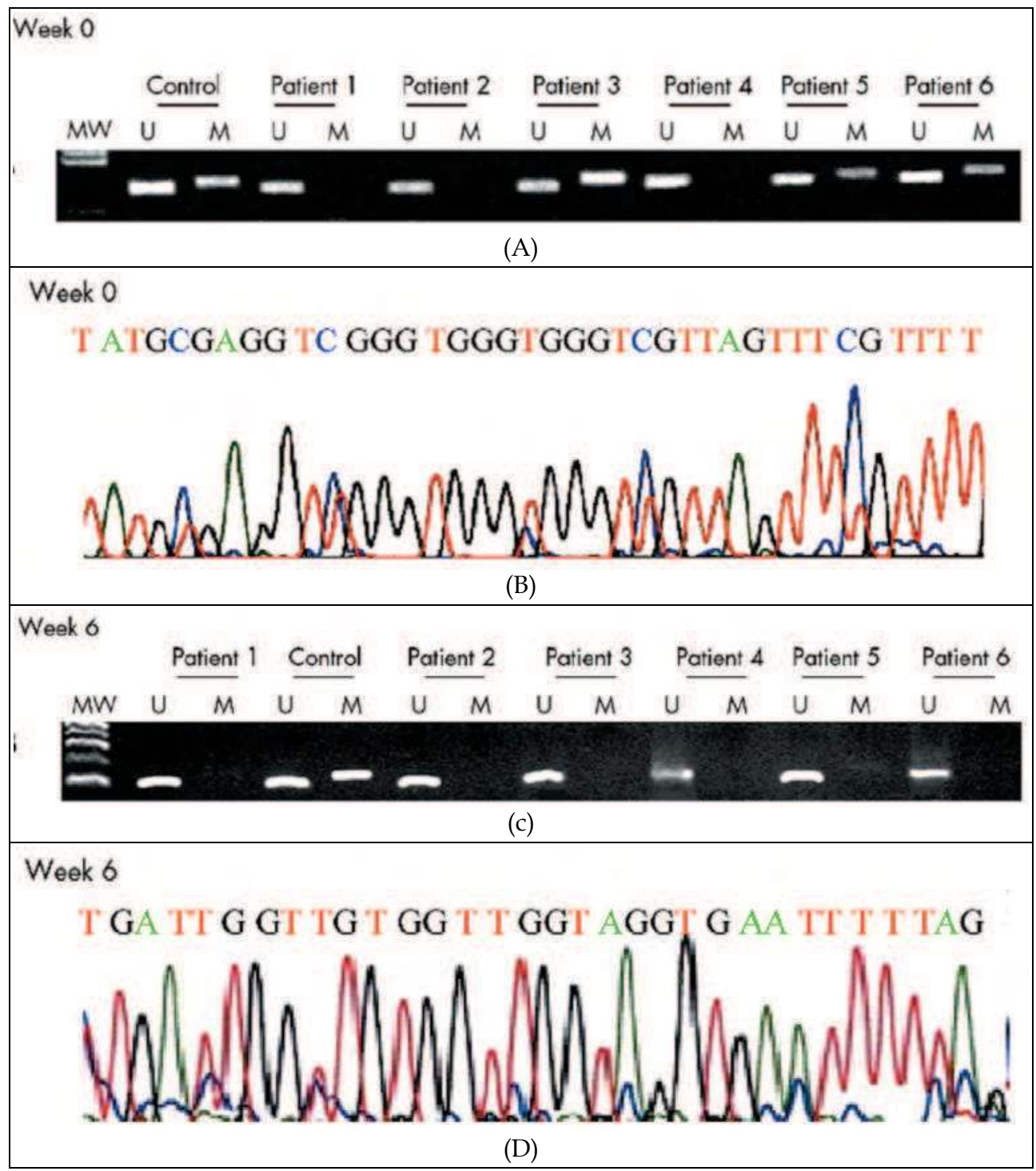

Fig. 2. CpG island methylation pattern at the E-cadherin gene in gastric mucosa from patients with dyspepsia. (A) Before eradication of $H$. pylori (week 0 ), methylation was present in patients 3,5 and 6. (B) The methylated product was confirmed by sequencing using the same methylated primer. (C) After eradication of H. pylori (week 6), methylation was not present in any patient. (D) The methylated product was again confirmed by sequencing using the same methylated primer. No methylated cytosine was seen. MW: molecular weight marker, U: unmethylated band, M: methylated band, red color: unmethylated cytosines converted to thymidine, blue color: methylated cytosines. Taken from Chan et al., Gut 2006;55: 463-8 with permission from BMJ Publishing Group Ltd. 
Recently, our group identified promotor DNA methylation of a novel gene, Reprimo (RPRM), not only in gastric mucosa but also in the plasma of gastric cancer patients (36). This methylated circulating cell-free DNA offers the opportunity for non-invasive detection of gastric cancer and premalignant gastritis. DNA methylation of promoter region of RPRM was initially identified by high-throughput microarray experiments that analyzed global changes in gene expression in pancreatic cancer cell lines treated with the demethylating agent 5-aza-2-deoxycitidine. Among 11 re-expressed genes, RPRM was highly re-expressed (45). Following this finding, the analysis of the methylation status of RPRM in clinical samples of pancreatic cancer identified a high frequency of DNA methylation of the promoter of RPRM (45). Subsequent research focused on different types of tumors (breast, esophagus, lymphoma, etc.) including gastric carcinoma (46). However, our study, not only looked into the methylation of RPRM in tumor tissues, but also in non-invasive plasma samples from the same patients (36). Interestingly, methylate circulating cell-free DNA of RPRM was found in over $90 \%$ in plasma from gastric cancer patients but less than $10 \%$ among asymptomatic controls (36). Thus, our results were the first to indicate that methylation of promoter region of RPRM might act as a potential biomarker for early detection of gastric cancer. RPRM is a downstream mediator of p53-induced G2 cell cycle arrest (47). When adenovirus expressing recombinant RPRM cDNA was infected into human colorectal cancer cell line DLD1, cell cycle arrest at the G2 phase was observed (47). However, it has been suggested that RPRM-induced cell cycle arrest is mediated by an indirect inhibition of Cdc2-CyclinB1 complex translocation to the nucleus (47). Recently, RPRM has also been proposed to be a tumor suppressor gene through in vitro colony formation assays (48). After RPRM transfection into the non-expressing renal cell carcinoma cell line SKRC39 there was a signicantly reduced number of G418 resistant colonies compared to the cell lines transfected with an empty vector control. However, it is unknown whether RPRM is a tumor suppressor in gastric cancer. A recent quantitative analysis of promoter DNA methylation of RPRM from Colombian residents from areas with high and low incidence of gastric cancer demonstrated an association with virulence factors cagA (including segments of the 30 end, encoding EPIYA polymorphisms) and vacA s1 and $\mathrm{m} 1$ regions of $H$. pylori strains (Fig. 3). This data suggest that cagA and vacA virulence determinants are significantly associated with DNA methylation of a specific gene, RPRM in high-risk gastritis (49). Thus, the posibility to detect DNA methylation of RPRM as a cellfree DNA in plasma in combination with H.pylori strains might opening the oportunity for a non-invasive detection of high-risk premalignant gastritis.

\section{Integration of histological and DNA methylation features of gastritis}

Although histological assessment of gastritis to search for premalignant conditions for the development of gastric cancer has been proposed (6) and epigenetic markers based on DNA methylation are associated with this progression (50), no integrative approach has been explore up to date for this two disparate fields. Recently, we have integrated histological together with in-situ molecular features to demonstrate that overexpression of p73 was probably the most important marker to identified high-risk premalignant gastritis (51). In that work, we analyse matched tumor/non-tumor adjacent mucosa of 91 early gastric cancer and 148 chronic gastritis cases for histological features by the Sydney and OLGA systems along with eight tissue markers to identified that overexpression of p73, severe atrophy, and OLGA stage IV were the most relevant features to identified high-risk gastritis (Fig. 4). 


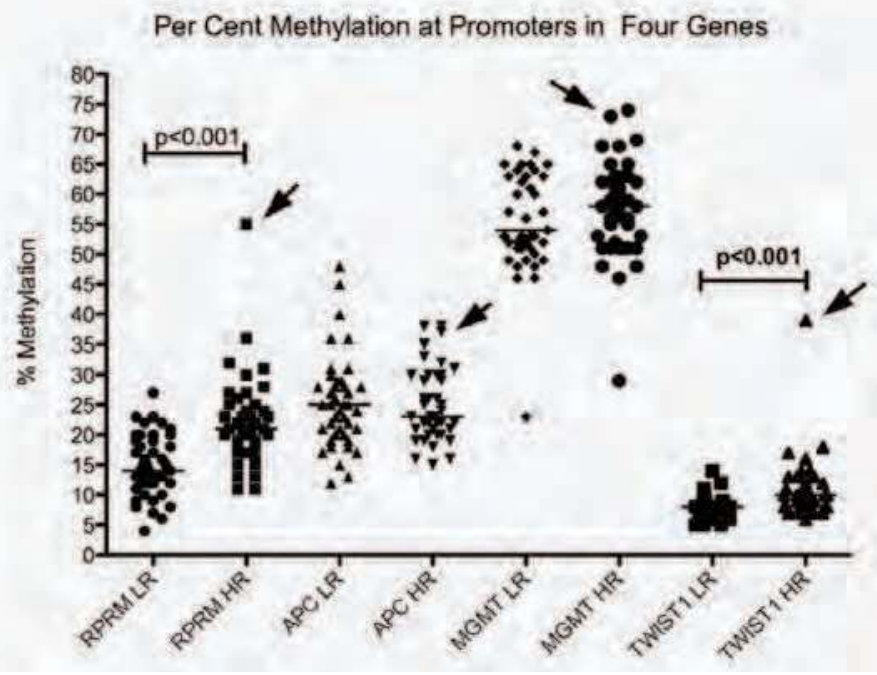

(A)

Table 3. Multivariate linear regression anaiysis

\begin{tabular}{|c|c|c|c|c|c|c|c|c|}
\hline \multirow[b]{3}{*}{ Variables } & \multicolumn{8}{|c|}{ Gene } \\
\hline & \multicolumn{2}{|c|}{$\operatorname{RPRM}(n=84)$} & \multicolumn{2}{|c|}{$A P C(n=84)$} & \multicolumn{2}{|c|}{$\operatorname{MGMT}(n=80)$} & \multicolumn{2}{|c|}{ TWIST1 $(n=82)$} \\
\hline & Coefficient (SE) & p-value & Coefficient (SE) & p-value & Coefficient (SE) & p-value & Coefficient (SE) & p-value \\
\hline \multicolumn{9}{|l|}{ Area } \\
\hline Low risk for gastric cancer & 0 & & 0 & & 0 & & 0 & \\
\hline High risk for gastric cancer & $6.4(1,4)$ & $<0.001$ & $1.0(1.5)$ & 0.511 & $-1.5(1.8)$ & 0.383 & $3.1(0.9)$ & 0.001 \\
\hline \multicolumn{9}{|l|}{ Diagnosis } \\
\hline Normat/NAG & 0 & & 0 & & 0 & & 0 & \\
\hline MAG & $1.1(2.0)$ & 0.583 & $-0.6(2.1)$ & 0.766 & $1.3(2.5)$ & 0.594 & $-0.4(1.4)$ & 0.746 \\
\hline m/ors & $0.2(1.7)$ & 0.926 & $-1.4(1.7)$ & 0.431 & $3.3(2.1)$ & 0.124 & $0.4(1,1)$ & 0.718 \\
\hline \multicolumn{9}{|l|}{ H. pylori genotypes } \\
\hline Uninfected & 0 & & 0 & & 0 & & 0 & \\
\hline Other genotypes. & $5.6(2.6)$ & 0.040 & $-9.3(2.9)$ & 0.002 & $5.3(3.1)$ & 0.104 & $0.6(1.7)$ & 0.746 \\
\hline $\operatorname{cog} A$ positive, vacA simt $1^{2}$ & $8.3(2.4)$ & 0.001 & $-9.9(2.6)$ & $<0.001$ & $11.2(2.9)$ & $<0.001$ & $1.8(1.6)$ & 0.244 \\
\hline Age in years & $-0.1(0.1)$ & 0.271 & $0.1(0.1)$ & 0.403 & $-0.1(0.1)$ & 0.598 & $-0.1(0.1)$ & 0.462 \\
\hline Adjusted $R^{2}$ & \multicolumn{2}{|l|}{0.3356} & \multicolumn{2}{|l|}{0.1267} & \multicolumn{2}{|l|}{0.2216} & \multicolumn{2}{|l|}{0.1281} \\
\hline
\end{tabular}

This category includes a subject with a strain of $H$. pylori that was cogA positive and vecA s 1 but which repeatedly failed PCR for vacA m. Abbreviations: SE: standard error: NAC: nonatrophic gastritis; MAG: multifocal atropbic gastritis: 1MA: intestinal metaplasia.

(B)

Fig. 3. Association between the percentage of methylation of RPRM in residents areas with low and high incidence of gastric cancer, and virulence factors CagA, VacA s1 and $\mathrm{m} 1$ regions of H. pylori. (A) Scatter plots indicate the percent methylation of each gene analysed, measured from DNA from residents of low-risk (LR) and high-risk (HR) areas. Arrows indicate the points representing the outlier subject, whose gastric histology showed widespread intestinal metaplasia and focal areas of indefinite dysplasia. (B) Multivariate regression models incorporated effects of geographic area, diagnosis, age and genotypes of the infecting $H$. pylori strain (classified as uninfected, cagA positive, vacAs1m1 and all other genotypes). Taken from Schneider et al., Int J Cancer 2010; 127: 2588-7 with permision from Wiley. 


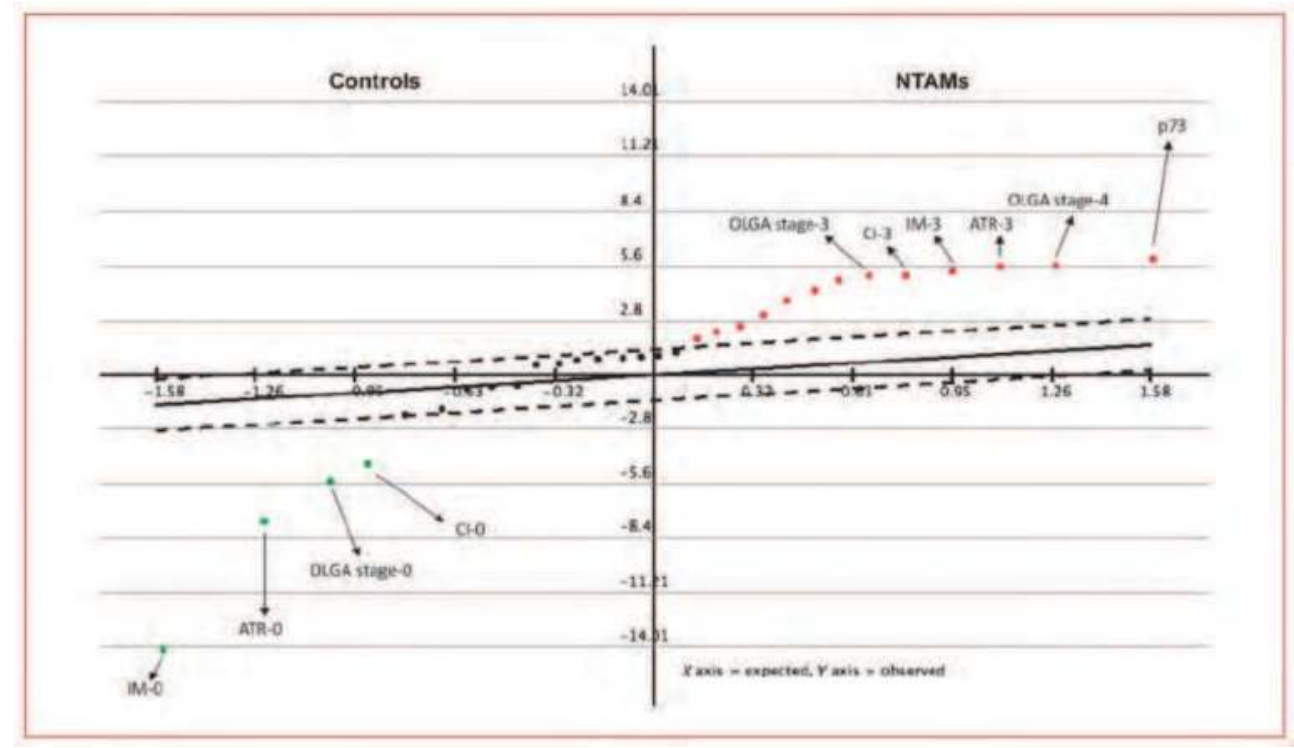

Fig. 4. Serial Analysis for Microarray from Non-tumor adjacent mucosa (NTAM) and and chronic gastritis controls. NTAM group is significantly characterized by the overexpression of p73, OLGA stages III to IV, and severe atrophy (ATR-3), intestinal metaplasia (IM-3), and chronic inflammation (CI-3) according to the Sydney System. Control group cases were significantly characterized by lack of intestinal metaplasia (IM-0), atrophy (ATR-0), and chronic inflammation (CI-0). False discovery rate $=0$. Taken from Carrasco et al., 2010 Clin.Cancer Res 16:3253-9.

Interestingly, further work have shown that p73 overexpression might be associated with hypo- or demethylation of the promoter region of p73 (52). Taken together these findings suggest that DNA methylation might play a role in gastritis and premalignant condition in both ways, inactivating or activating tumor-related genes by hypermethylation or demethylation of promoter region of specific genes, respectively.

\section{Conclusions}

In conclusion, specific histological features with increasing risk to progress to gastric cancer can be assessed by OLGA system. Specific DNA methylation changes might play a major role in premalignant gastritis and might be associated with $H$. pylori infection. These changes are accumulative from bening to fully malignant conditions. Induced DNA methylation in specific genes by H.pylori might be reversible and might be associated with virulence of H.pylori strains. These DNA methylated genes might be detected in plasma (i.e. RPRM) as a circulating cell-free DNA. Integrative analysis of histological features of premalignant conditions with overexpression of specific genes such as p73 by demethylation might be important to identified the best biomarkers for high-risk premalignant gastritis for the development of gastric cancer. 


\section{Aknowledgements}

We thank Natalia Saez for premium editing and proofreading of the manuscript.

\section{Grant support}

Grants-in-Aid for Fondo Nacional de Ciencia y Tecnologia (FONDECYT) \#1111014 and Fondo de Fomento al Desarrollo Científico y Tecnológico (FONDEF) \#D09i1137 to A.H. Corvalan from the Government of Chile.

\section{References}

[1] Figura N, Oderda G. Reflections on the first description of the presence of Helicobacter species in the stomach of mammals. Helicobacter. 1996;1:4-5.

[2] Kidd M, Modlin IM. A century of Helicobacter pylori: paradigms lost-paradigms regained. Digestion. 1998;59:1-15.

[3] Schindler R. Gastritis. London: William Heinmann (Medical Books); 1947.

[4] Marshall BJ, Warren JR. Unidentified curved bacilli in the stomach of patients with gastritis and peptic ulceration. Lancet. 1984;1:1311-5.

[5] Faber K. Gastritis and Its Consequences. London: Oxford University Press; 1935.

[6] Rugge M, Fassan M, Pizzi M, Pennelli G, Nitti D, Farinati F. Operative Link for Gastritis Assessment gastritis staging incorporates intestinal metaplasia subtyping. Hum Pathol. 2011.

[7] Dixon MF, Genta RM, Yardley JH, Correa P. Classification and grading of gastritis. The updated Sydney System. International Workshop on the Histopathology of Gastritis, Houston 1994. Am J Surg Pathol. 1996;20:1161-81.

[8] Rugge M, Correa P, Dixon MF, Fiocca R, Hattori T, Lechago J, et al. Gastric mucosal atrophy: interobserver consistency using new criteria for classification and grading. Aliment Pharmacol Ther. 2002;16:1249-59.

[9] Rugge M, Meggio A, Pennelli G, Piscioli F, Giacomelli L, De Pretis G, et al. Gastritis staging in clinical practice: the OLGA staging system. Gut. 2007;56:631-6.

[10] Niwa T, Tsukamoto T, Toyoda T, Mori A, Tanaka H, Maekita T, et al. Inflammatory processes triggered by Helicobacter pylori infection cause aberrant DNA methylation in gastric epithelial cells. Cancer Res. 2010;70:1430-40.

[11] Correa P. A human model of gastric carcinogenesis. Cancer Res. 1988;48:3554-60.

[12] Correa P, Haenszel W, Cuello C, Zavala D, Fontham E, Zarama G, et al. Gastric precancerous process in a high risk population: cross-sectional studies. Cancer Res. 1990;50:4731-6.

[13] Stemmermann GN. Intestinal metaplasia of the stomach. A status report. Cancer. 1994;74:556-64.

[14] Fearon ER, Vogelstein B. A genetic model for colorectal tumorigenesis. Cell. 1990;61:759-67.

[15] Hanahan D, Weinberg RA. Hallmarks of cancer: the next generation. Cell. 2011;144:646-74.

[16] Kim JH, Takahashi T, Chiba I, Park JG, Birrer MJ, Roh JK, et al. Occurrence of p53 gene abnormalities in gastric carcinoma tumors and cell lines. J Natl Cancer Inst. 1991;83:938-43. 
[17] Falck VG, Gullick WJ. c-erbB-2 oncogene product staining in gastric adenocarcinoma. An immunohistochemical study. J Pathol. 1989;159:107-11.

[18] Yonemura Y, Ninomiya I, Yamaguchi A, Fushida S, Kimura H, Ohoyama S, et al. Evaluation of immunoreactivity for erbB-2 protein as a marker of poor short term prognosis in gastric cancer. Cancer Res. 1991;51:1034-8.

[19] Carneiro F, Oliveira C, Leite M, Seruca R. Molecular targets and biological modifiers in gastric cancer. Semin Diagn Pathol. 2008;25:274-87.

[20] Becker KF, Atkinson MJ, Reich U, Becker I, Nekarda H, Siewert JR, et al. E-cadherin gene mutations provide clues to diffuse type gastric carcinomas. Cancer Res. 1994;54:3845-52.

[21] Ascano JJ, Frierson H, Jr., Moskaluk CA, Harper JC, Roviello F, Jackson CE, et al. Inactivation of the E-cadherin gene in sporadic diffuse-type gastric cancer. Mod Pathol. 2001;14:942-9.

[22] Semba S, Yokozaki H, Yasui W, Tahara E. Frequent microsatellite instability and loss of heterozygosity in the region including BRCA1 (17q21) in young patients with gastric cancer. Int J Oncol. 1998;12:1245-51.

[23] Tamura G. Alterations of tumor suppressor and tumor-related genes in the development and progression of gastric cancer. World J Gastroenterol. 2006;12:1928.

[24] Jankowski JA, Odze RD. Biomarkers in gastroenterology: between hope and hype comes histopathology. Am J Gastroenterol. 2009;104:1093-6.

[25] Esteller M, Herman JG. Cancer as an epigenetic disease: DNA methylation and chromatin alterations in human tumours. J Pathol. 2002;196:1-7.

[26] Fleisher AS, Esteller M, Wang S, Tamura G, Suzuki H, Yin J, et al. Hypermethylation of the hMLH1 gene promoter in human gastric cancers with microsatellite instability. Cancer Res. 1999;59:1090-5.

[27] Callinan PA, Feinberg AP. The emerging science of epigenomics. Hum Mol Genet. 2006;15 Spec No 1:R95-101.

[28] Corvalán AH, Maturana MJ. Recent Patents of DNA Methylation Biomarkers in Gastrointestinal Oncology. Recent Pat DNA Gene Seq. 2010;4:202-9.

[29] Herman JG, Baylin SB. Gene silencing in cancer in association with promoter hypermethylation. N Engl J Med. 2003;349:2042-54.

[30] Jones PA, Baylin SB. The fundamental role of epigenetic events in cancer. Nat Rev Genet. 2002;3:415-28.

[31] Kopelovich L, Crowell JA, Fay JR. The epigenome as a target for cancer chemoprevention. J Natl Cancer Inst. 2003;95:1747-57.

[32] Chan AO, Peng JZ, Lam SK, Lai KC, Yuen MF, Cheung HK, et al. Eradication of Helicobacter pylori infection reverses E-cadherin promoter hypermethylation. Gut. 2006; 55:463-8.

[33] Wu DL, Sui FY, Jiang XM, Jiang XH. Methylation in esophageal carcinogenesis. World J Gastroenterol. 2006;12:6933-40.

[34] Hamilton JP, Sato F, Jin Z, Greenwald BD, Ito T, Mori Y, et al. Reprimo methylation is a potential biomarker of Barrett's-Associated esophageal neoplastic progression. Clin Cancer Res. 2006;12:6637-42.

[35] Bernal C, Vargas M, Ossandón FJ, Santibáñez E, Urrutia J, Luengo V, et al. DNA methylation profile in diffuse type gastric cancer: evidence for hypermethylation of 
the BRCA1 promoter region in early-onset gastric carcinogenesis. Biological research. 2008;41:303-15.

[36] Bernal C, Aguayo FR, Villarroel C, Vargas M, Diaz I, Ossandón FJ, et al. Reprimo as a potential biomarker for early detection in gastric cancer. Clin Cancer Res. 2008;14:6264-9.

[37] Fraga MF, Esteller M. DNA methylation: a profile of methods and applications. Biotechniques. 2002;33:632, 4, 6-49.

[38] Clark SJ, Harrison J, Paul CL, Frommer M. High sensitivity mapping of methylated cytosines. Nucleic Acids Res. 1994;22:2990-7.

[39] Herman JG, Graff JR, Myohanen S, Nelkin BD, Baylin SB. Methylation-specific PCR: a novel PCR assay for methylation status of CpG islands. Proc Natl Acad Sci U S A. 1996;93:9821-6.

[40] Kang GH, Shim YH, Jung HY, Kim WH, Ro JY, Rhyu MG. CpG island methylation in premalignant stages of gastric carcinoma. Cancer Res. 2001;61:2847-51.

[41] Kang GH, Lee HJ, Hwang KS, Lee S, Kim JH, Kim JS. Aberrant CpG island hypermethylation of chronic gastritis, in relation to aging, gender, intestinal metaplasia, and chronic inflammation. Am J Pathol. 2003;163:1551-6.

[42] Chan AO, Lam SK, Wong BC, Wong WM, Yuen MF, Yeung YH, et al. Promoter methylation of E-cadherin gene in gastric mucosa associated with Helicobacter pylori infection and in gastric cancer. Gut. 2003;52:502-6.

[43] Maekita T, Nakazawa K, Mihara M, Nakajima T, Yanaoka K, Iguchi M, et al. High levels of aberrant DNA methylation in Helicobacter pylori-infected gastric mucosae and its possible association with gastric cancer risk. Clin Cancer Res. 2006; 12:98995.

[44] Leung WK, Man EP, Yu J, Go MY, To KF, Yamaoka Y, et al. Effects of Helicobacter pylori eradication on methylation status of E-cadherin gene in noncancerous stomach. Clin Cancer Res. 2006;12:3216-21.

[45] Sato N, Fukushima N, Maitra A, Matsubayashi H, Yeo CJ, Cameron JL, et al. Discovery of novel targets for aberrant methylation in pancreatic carcinoma using highthroughput microarrays. Cancer Res. 2003;63:3735-42.

[46] Takahashi T, Suzuki M, Shigematsu H, Shivapurkar N, Echebiri C, Nomura M, et al. Aberrant methylation of Reprimo in human malignancies. Int $\mathrm{J}$ Cancer. 2005;115:503-10.

[47] Ohki R, Nemoto J, Murasawa H, Oda E, Inazawa J, Tanaka N, et al. Reprimo, a new candidate mediator of the p53-mediated cell cycle arrest at the G2 phase. J Biol Chem. 2000;275:22627-30.

[48] Morris MR, Ricketts C, Gentle D, Abdulrahman M, Clarke N, Brown M, et al. Identification of candidate tumour suppressor genes frequently methylated in renal cell carcinoma. Oncogene. 2010;29:2104-17.

[49] Schneider BG, Peng DF, Camargo MC, Piazuelo MB, Sicinschi LA, Mera R, et al. Promoter DNA hypermethylation in gastric biopsies from subjects at high and low risk for gastric cancer. Int J Cancer. 2010;127:2588-97.

[50] Nakajima T, Yamashita S, Maekita T, Niwa T, Nakazawa K, Ushijima T. The presence of a methylation fingerprint of Helicobacter pylori infection in human gastric mucosae. Int J Cancer. 2009;124:905-10. 
[51] Carrasco G, Diaz J, Valbuena JR, Ibanez P, Rodriguez P, Araya G, et al. Overexpression of p73 as a tissue marker for high-risk gastritis. Clin Cancer Res. 2010;16:3253-9.

[52] Corvalán AH, Villarroel C, Ibanez P, Carrasco G, Rodriguez C, Rodriguez P, et al. Demethylation of promoter region of $\mathrm{p} 73$ gene as a mechanism of overexpression of p73 protein in gastric carcinoma: Analysis by demethylation, microdissection of gastric epithelial cells and tissue microarray. AACR Meeting 2008; A4461. 


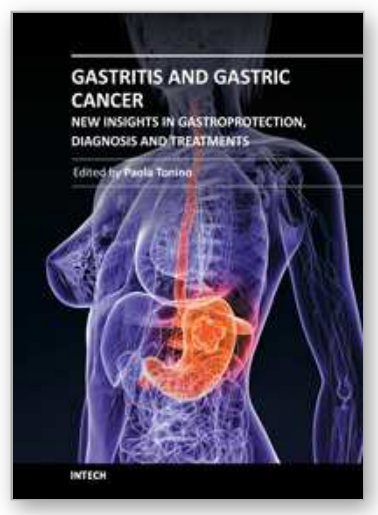

\section{Gastritis and Gastric Cancer - New Insights in Gastroprotection, Diagnosis and Treatments}

Edited by Dr. Paola Tonino

ISBN 978-953-307-375-0

Hard cover, 296 pages

Publisher InTech

Published online 15, September, 2011

Published in print edition September, 2011

This book is a comprehensive overview of invited contributions on Helicobacter pylori infection in gastritis and gastric carcinogenesis. The first part of the book covers topics related to the pathophysiology of gastric mucosal defense system and gastritis including the gastroprotective function of the mucus, the capsaicinsensitive afferent nerves and the oxidative stress pathway involved in inflammation, apoptosis and autophagy in $\mathrm{H}$. pylori related gastritis. The next chapters deal with molecular pathogenesis and treatment, which consider the role of neuroendocrine cells in gastric disease, DNA methylation in $\mathrm{H}$. pylori infection, the role of antioxidants and phytotherapy in gastric disease. The final part presents the effects of cancer risk factors associated with $\mathrm{H}$. pylori infection. These chapters discuss the serum pepsinogen test, $\mathrm{K}$-ras mutations, cell kinetics, and $\mathrm{H}$. pylori lipopolysaccharide, as well as the roles of several bacterial genes (cagA, $\operatorname{cag} \mathrm{T}$, $\operatorname{vacA}$ and dupA) as virulence factors in gastric cancer, and the gastrokine-1 protein in cancer progression.

\section{How to reference}

In order to correctly reference this scholarly work, feel free to copy and paste the following:

Alejandro H. Corvalán, Gonzalo Carrasco and Wilda Olivares (2011). Molecular Pathology of Gastritis, Gastritis and Gastric Cancer - New Insights in Gastroprotection, Diagnosis and Treatments, Dr. Paola Tonino (Ed.), ISBN: 978-953-307-375-0, InTech, Available from: http://www.intechopen.com/books/gastritis-and-gastriccancer-new-insights-in-gastroprotection-diagnosis-and-treatments/molecular-pathology-of-gastritis

\section{INTECH}

open science | open minds

\author{
InTech Europe \\ University Campus STeP Ri \\ Slavka Krautzeka 83/A \\ 51000 Rijeka, Croatia \\ Phone: +385 (51) 770447 \\ Fax: +385 (51) 686166 \\ www.intechopen.com
}

\author{
InTech China \\ Unit 405, Office Block, Hotel Equatorial Shanghai \\ No.65, Yan An Road (West), Shanghai, 200040, China \\ 中国上海市延安西路65号上海国际贵都大饭店办公楼 405 单元 \\ Phone: +86-21-62489820 \\ Fax: $+86-21-62489821$
}


(C) 2011 The Author(s). Licensee IntechOpen. This chapter is distributed under the terms of the Creative Commons Attribution-NonCommercialShareAlike-3.0 License, which permits use, distribution and reproduction for non-commercial purposes, provided the original is properly cited and derivative works building on this content are distributed under the same license. 